\title{
Comparison of Safflower Cultivation in Two Seasons in the South of Brazil
}

\author{
Marinez Carpiski Sampaio ${ }^{1}$, Reginaldo Ferreira Santos ${ }^{2}$, Paulo Sérgio Rabello de Oliveira ${ }^{1}$, Doglas Bassegio ${ }^{2}$, \\ Carlos Augusto Rocha de Moraes Rego ${ }^{1}$, Lucas da Silveira ${ }^{1}$, Bruna Penha Costa $^{1}$, Eloisa Mattei ${ }^{1}$ \\ \& Juan López de Herrera ${ }^{3}$ \\ ${ }^{1}$ West State University of Paraná (UNIOESTE), Marechal Cândido Rondon, Brazil \\ ${ }^{2}$ West State University of Paraná (UNIOESTE), Cascavel, Brazil \\ ${ }^{3}$ Technical University of Madrid (UPM), Madrid, Spain \\ Correspondence: Marinez Carpiski Sampaio, West State University of Paraná (UNIOESTE), Marechal Cândido \\ Rondon, Brazil. Tel: 55-45-99970-6661. E-mail: mari_marinez@hotmail.com
}

$\begin{array}{ll}\text { Received: January 27, } 2018 & \text { Accepted: March 1, } 2018 \quad \text { Online Published: April 15, } 2018 \\ \text { doi:10.5539/jas.v10n5p92 } & \text { URL: https://doi.org/10.5539/jas.v10n5p92 }\end{array}$

\begin{abstract}
The objective of this work was to evaluate the production components, grain yield and safflower character correlations as a function of two sowing seasons (autumn and winter). Safflower culture was implanted in 2014 in a randomized complete block design with three replicates. The evaluation of safflower crop occurred in two seasons of the year, with the first growing season being characterized by sowing on April 30, 2014 (autumn), and the second growing season on July 30, 2014 (winter). The evaluations occur when the plants showed a 50\% flowering and the following determination: plant height, number of branches per plant and chapters, stem diameter, dry weight of the stalk, dry mass of the branches dry mass of chapters and mass dry roots, grain yield, oil content and oil productivity. Growth stations were compared at 5\% probability of error by the Student $t$ test. For the study of correlations, Pearson's linear correlation coefficient matrix (r) was estimated between the characters by means of the Student's t-test, with a 5\% probability of error. Except for the oil content and number of branches, safflower characters were benefited by early sowing in autumn. Safflower cultivated in autumn produced $3,820 \mathrm{~kg} \mathrm{ha}^{-1}$ and in winter yielded $2,068 \mathrm{~kg} \mathrm{ha}^{-1}$. For the early cultivation of autumn, the characters have greater correlation, favored by the climatic conditions. Grain and oil productivity obtained correlation higher than $97 \%$ in both seasons.
\end{abstract}

Keywords: Carthamus tinctorius L., sowing time, yield

\section{Introduction}

The rise in concern for the preservation of the environment, together with the need to increase energy generation, results in the search for oleaginous alternatives to bioenergy production, such as safflower (Carthamus tinctorius L.) (Santos \& Silva, 2015). Safflower is a crop with characteristics of easy adaptation to the Brazilian conditions, high potential of production and with satisfactory development in diverse types of soil (Santos et al., 2015).

For the species to stand out in the national scenario, an important component is the climate, because its variations can mean the difference between success and failure of a harvest (Barteko et al., 2010). The southern region of Brazil has large climatic variations, with climate that ranges from tropical to typical temperate, with hot summers, winter with sensitive temperature drop, the largest annual temperature range of the country and annual regular rainfall, which enables varied crop species (Wrege et al., 2009).

The development of safflower cultivation is influenced by the environmental conditions under which it is presented. The sowing season is an important factor that directly interferes with the agronomic characteristics and crop yield (Peixoto et al., 2008). Different research has shown the effects of sowing on yield, yield component and other agronomic characteristics of the crop (Mostafanezhad \& Eivazi, 2010; Koutroubas et al., 2004). Late sowing may be responsible for the yield decline of safflower seeds, since the last flowering may not survive the high temperature and water deficit at the end of the season (Yau, 2007; Omidi \& Sharifmoghadas, 2010). The plant's development period is directly linked to its productivity. Thus, late sowing will be responsible for acceleration in the maturation phase due to the shorter development period, which leads to decrease 
production (Tayebi et al., 2012). According to Si and Walton (2004), early sowing is associated with an early flowering cultivar allows higher productive performance.

Studies conducted in different localities have shown that safflower may be a winter or spring crop option in a place with mild temperatures, although its yield is better when sown in autumn (Koutroubas et al., 2004; Yau, 2007). The sowing in hot areas of the Mediterranean, such as California, cultivation is carried out in the spring avoiding excessive development, as it will lead to the production of low quality seeds (Kaffka \& Kearney, 1998). Crops in central Italy, with low temperatures in the Mediterranean, have shown lower productivity, due to the low resistance of the species to low temperatures during its initial development (Salera, 1997). However, in southern Italy, a low temperature site, sowing in the autumn provided better yields than spring sowing (Corleto et al., 2001).

In view of the above, the objective of this research was to evaluate the components of production, grain yield and correlation of safflower characters as a function of two sowing seasons (autumn and winter) in southern Brazil.

\section{Material and Methods}

The cultivation of safflower was established in 2014 at the Centro de Desenvolvimento e Diffusion de Tecnologia (CEDETEC), Faculdade Assis Gurgacz (FAG), located in the municipality of Cascavel, PR, Brazil, whose geographical coordinates are $24^{\circ} 56^{\prime} 40^{\prime \prime} \mathrm{S}$ and $53^{\circ} 30^{\prime} 31^{\prime \prime} \mathrm{W}$, with an average elevation of $715 \mathrm{~m}$. The climate of the region is type $\mathrm{Cfa}$, according to the Köppen classification, that is, temperate mesothermic superhumid, with moderate temperatures, well distributed rains and hot summer (Alvares et al., 2014). The soil of the experimental area was classified as Dystrophic Red Latosol (Santos et al., 2013).

The experimental design was a randomized complete block design, with three replicates, each block being divided into 5 plots, 5 meters by 4 meters, with a total area of $100 \mathrm{~m}^{2}$ per block. The area of experimentation under no-tillage system for more than 20 years, with corn or soybean crops in the summer and oat or wheat crops in the autumn/winter seasons.

Soil chemical analysis showed in autumn, $\mathrm{pH}$ in $\mathrm{CaCl}_{2} 0.01 \mathrm{M}$ of $5.2,38.2 \mathrm{~g} \mathrm{~kg}^{-1}$ of organic matter, $12.8 \mathrm{mg} \mathrm{dm}^{-3}$ of $\mathrm{P}\left(\right.$ Mehlich $\left.{ }^{-1}\right), 1.3 \mathrm{cmolc} \mathrm{dm}^{-3}$ of $\mathrm{K}, 4.6 \mathrm{cmolc} \mathrm{dm}^{-3}$ of $\mathrm{Ca}, 2.2 \mathrm{cmolc} \mathrm{dm}^{-3}$ of $\mathrm{Mg}, 14.3 \mathrm{cmolc} \mathrm{dm}^{-3}$ of CEC, and $59 \%$ of soil base saturation. In winter, it showed $\mathrm{pH}$ in $\mathrm{CaCl}_{2} 0.01 \mathrm{M}$ of $5.48,46.48 \mathrm{~g} \mathrm{~kg}^{-1}$ of organic matter, $5.48 \mathrm{mg} \mathrm{dm}^{-3}$ of $\mathrm{P}\left(\mathrm{Mehlich}^{-1}\right), 0.8 \mathrm{cmolc} \mathrm{dm}^{-3}$ of K, $4.5 \mathrm{cmolc} \mathrm{dm}^{-3}$ of Ca, $2.8 \mathrm{cmolc} \mathrm{dm}^{-3}$ of $\mathrm{Mg}, 13.3 \mathrm{cmolc}$ $\mathrm{dm}^{-3}$ of CEC, and $61 \%$ of soil base saturation.

The evaluation of safflower crop was made with sowing in two seasons of the year, in the first plot sowing on April 30, 2014 (autumn) and the second plot sowing on July 30, 2014 (winter). The sowing was done manually, leaving 10 plants per linear meter after the thinning. Each evaluation plot consisted of four rows measuring 4 meters long.

When the plants showed 50\% flowering, at 80 and 60 days after emergence for the first and second sowing seasons respectively, the height of plants was determined, measured with graduated tape measure, the distance between the soil level to the apex of in the plant, of six plants at random within each plot. The number of branches per plants and chapters was determined from this six plant. When the crop presented $50 \%$ of its flowering, six plants were randomly collected in each plot to measure the diameter of the stem, with a digital caliber we measure the basal region of the stem. This safflower plants were separated into stem, twigs, chapters and roots to determine the amount of dry matter by dried $338.15 \mathrm{~K}$ in a constant weight oven.

The harvest was made, at 160 and 140 days after the emergence in the first and second sowing seasons respectively. Yield was determined after manual threshing and cleaning the grain harvested from plants collected from a linear meter from each plot, with values expressed in $\mathrm{kg} \mathrm{ha}^{-1}$, correcting the moisture content to $12 \%$. The mass of 1000 grains was performed by score sub samples of 100 grains per plot. The samples were weighed in precision scale with two decimal places, correcting the degree of humidity to $12 \%$. The mass of 1000 grains was determined according to the Rules for Seed Analysis (Ministério da Agricultura, Pecuária e Abastecimento, 2009).

Oil content was determined from a TD-NMR in a SLK-SG-200 spectrometer (SpinLock Magnetic Resonance Solutions) at $571,3 \mathrm{~K}$, equipped with a permanent magnet of $0.23 \mathrm{~T}(9 \mathrm{MHz}$ for $1 \mathrm{H})$ and a probe with $13 \mathrm{~mm} \times$ $30 \mathrm{~mm}$ of useful area. We used the Condor IDE software with CPMG pulse sequence and Qdamper (Colnago et al., 2011), expressed on a dry basis (\% DB).

Growth stations were compared at $5 \%$ probability of error by the Student $t$ test. For the study of correlations, Pearson's linear correlation coefficient matrix (r) was estimated between the characters by means of the Student's t-test, with a $5 \%$ probability of error. Data from the two experiments were also submitted to principal 
component analysis (PCA). The Minitab 17 software (Minitab, Inc., State College PA, USA) was used to perform analysis of the results.

\section{Results and Discussion}

Safflower cultivated in the autumn period received about $1,170 \mathrm{~mm}$ of precipitation, which is above the winter precipitation $(600 \mathrm{~mm})$ and above the required amount throughout the cycle for optimal growth, since it is necessary values between 800 and 1,000 mm (Oyen \& Umali, 2007). In addition, the cultivation in the autumn favored the crop due to the larger photoperiod and the long day favor and advances the plant cycle, since the solar interception is greater.

Except for the oil content (OIL) and number of branches (NG), the safflower characters were benefited by early sowing in autumn (Table 1). This is due to the lower effect of the environment in these characters, but also to due to the characteristics of the plant itself, as suggested by Brăileanu et al. (2013). The oil content in the present work is similar to the values of Elfadl et al. (2009), which varied from 19.0 to $26.1 \%$.

Table 1. Safflower characters in autumn and winter crop

\begin{tabular}{lllllllllllll}
\hline Season & AP & DC & CC & MSC & NG & MSG & NC & MSCA & PRO & TGW & OIL & PRO.O \\
\hline Autumn & $1.2 \mathrm{a}$ & $10.6 \mathrm{a}$ & $0.8 \mathrm{a}$ & $16.3 \mathrm{a}$ & $6.4 \mathrm{a}$ & $19.8 \mathrm{a}$ & $12.5 \mathrm{a}$ & $16.2 \mathrm{a}$ & $3820 \mathrm{a}$ & $68.7 \mathrm{a}$ & $23.5 \mathrm{a}$ & $907 \mathrm{a}$ \\
Winter & $0.7 \mathrm{~b}$ & $8.3 \mathrm{~b}$ & $0.5 \mathrm{~b}$ & $7.7 \mathrm{~b}$ & $6.8 \mathrm{a}$ & $5.9 \mathrm{~b}$ & $9.3 \mathrm{~b}$ & $6.2 \mathrm{~b}$ & $2068 \mathrm{~b}$ & $48.4 \mathrm{~b}$ & $24.2 \mathrm{a}$ & $520 \mathrm{~b}$ \\
\hline
\end{tabular}

Note. Letters in the column indicate difference at $5 \%$ of probability of error by Student's $t$ test. AP $=$ Plant height, in $\mathrm{cm} ; \mathrm{DC}=$ stem diameter, in $\mathrm{mm} ; \mathrm{CC}=$ Length of stem in $\mathrm{cm} ; \mathrm{MSC}=$ Dry matter of stem, in $\mathrm{g} \mathrm{plant}^{-1} . \mathrm{NG}=$ Number of branches; MSG $=$ Dry matter of branches, in $g_{\text {plant }}{ }^{-1} ; \mathrm{NC}=$ Number of chapters; MSCA $=$ Dry matter of chapters, in $\mathrm{g} \mathrm{plant}^{-1}$; PRO $=$ Grain yield, in $\mathrm{kg} \mathrm{ha}^{-1}$; TGW $=$ Weight of a thousand grains, in $\mathrm{g} \mathrm{plant}^{-1}$; $\mathrm{OIL}=$ oil content in \%; PRO.O $=$ Oil productivity, in $\mathrm{kg} \mathrm{ha}^{-1}$.

The safflower cultivated in autumn obtained better climatic conditions for the growth, flowering and filling of grains, thus, the accumulation of dry matter in the plant parts and in the chapters and the consequent productivity of grains was benefited by the early sowing. These results show that late sowing presents a significant decrease in these characters due to water deficit and high temperatures at the end of the cycle, which was also observed by Rao (1990), and Ashri (1975).

The water deficit has been pointed out as responsible for the reduction of safflower characters and grain yield (Lovelli et al., 2007), especially in the vegetative stage (Istanbulluoglu, 2009; Istanbulluoglu et al., 2009). Bellé et al. (2012) in Southern Brazil observed a lower accumulation of dry matter in spring-summer sowing in relation to autumn-winter, due to high evapotranspiration values. The results of this study are also agree with the results reported by Ghanbari-Odivi et al. (2013) in Iran, where higher productivity was observed with sowing in May (autumn) compared to January (winter). Positive results of autumn sowing are reported in the literature (Koutroubas et al., 2004; Yau, 2007).

Although contrasting with the environment, the average yield $\left(2.068 \mathrm{~kg} \mathrm{ha}^{-1}\right)$ observed in late winter cultivation in southern Brazil is between 1000-3300 kg ha ${ }^{-1}$ obtained in Pampa region of Argentina (Quiroga et al., 2001), in Potenza in Italy (Lovelli et al., 2007) and in Orissa in India (Kar et al., 2007).

The linear association of AP with the characters in autumn and winter, with the exception of CC, showed values of $\mathrm{r}$ of low magnitude, that is, the height of safflower plants is not associated with the production components (Tables 2 and 3). The highest correlation between AP and CC in winter is due to lower solar interception, which is reflected by the degree of intraspecific competition of plants. 
Table 2. Pearson (r) linear correlation coefficients among the safflower characters in winter

\begin{tabular}{lllllllllllll}
\hline Characters & AP & DC & CC & MSC & NG & MSG & NC & MSCA & PRO & TGW & OIL & PRO.O \\
\hline AP & 1 & -0.12 & $0.69^{* *}$ & 0.16 & $-0.27^{*}$ & -0.17 & -0.25 & -0.24 & 0.19 & 0.10 & 0.06 & 0.15 \\
DC & -0.12 & 1 & $-0.54^{* *}$ & $0.76^{* *}$ & $0.77^{* *}$ & $0.87^{* *}$ & $0.84^{* *}$ & $0.82^{* *}$ & -0.24 & 0.13 & -0.03 & -0.22 \\
CC & $0.69^{* *}$ & $-0.54^{* *}$ & 1 & $-0.34^{*}$ & $-0.56^{* *}$ & $-0.64^{* *}$ & $-0.68^{* *}$ & $-0.68^{* *}$ & 0.15 & -0.08 & -0.02 & 0.11 \\
MSC & 0.16 & $0.76^{* *}$ & $-0.34^{*}$ & 1 & $0.69^{* *}$ & $0.82^{* *}$ & $0.82^{* *}$ & $0.76^{* *}$ & -0.19 & 0.08 & -0.03 & -0.18 \\
NG & $-0.27^{* *}$ & $0.77^{* *}$ & $-0.56^{* *}$ & $0.69^{* *}$ & 1 & $0.84^{* *}$ & $0.86^{* *}$ & $0.75^{* *}$ & $-0.28^{*}$ & 0.03 & -0.02 & $-0.25^{*}$ \\
MSG & -0.17 & $0.87^{* *}$ & $-0.64^{* *}$ & $0.82^{* *}$ & $0.84^{* *}$ & 1 & $0.94^{* *}$ & $0.92^{* *}$ & $-0.29^{*}$ & 0.07 & -0.05 & $-0.27^{*}$ \\
NC & -0.25 & $0.84^{* *}$ & $-0.68^{* *}$ & $0.82^{* *}$ & $0.86^{* *}$ & $0.94^{* *}$ & 1 & $0.91^{* *}$ & -0.22 & 0.13 & -0.01 & -0.20 \\
MSCA & -0.24 & $0.82^{* *}$ & $-0.68^{* *}$ & $0.76^{* *}$ & $0.75^{* *}$ & $0.92^{* *}$ & $0.91^{* *}$ & 1 & -0.25 & 0.08 & -0.04 & -0.22 \\
PRO & 0.19 & -0.24 & 0.15 & -0.19 & $-0.28^{*}$ & $-0.29^{*}$ & -0.22 & -0.25 & 1 & $0.26^{*}$ & $0.38^{* *}$ & $0.98^{* *}$ \\
TGW & 0.10 & 0.13 & -0.08 & 0.08 & 0.03 & 0.07 & 0.13 & 0.08 & $0.26^{*}$ & 1 & 0.08 & 0.23 \\
OIL & 0.06 & -0.03 & -0.02 & -0.03 & -0.02 & -0.05 & -0.01 & -0.04 & $0.38^{* *}$ & 0.08 & 1 & $0.53^{* *}$ \\
PRO.O & 0.15 & -0.22 & 0.11 & -0.18 & $-0.25^{*}$ & $-0.27^{*}$ & -0.20 & -0.22 & $0.98^{* *}$ & 0.23 & $0.53^{* *}$ & 1
\end{tabular}

Note. ${ }^{*}$ Significant at $5 \%$ probability of error by Student's t-test, ${ }^{* *}$ Significant at $1 \%$ probability of error by Student's t-test. Legend: AP = Height of plant, in $\mathrm{cm} ; \mathrm{DC}=$ stem diameter, in $\mathrm{mm} ; \mathrm{CC}=$ Length of stem in $\mathrm{cm}$; $\mathrm{MSC}=$ Dry matter of stem, in $\mathrm{g} \mathrm{plant}^{-1} . \mathrm{NG}=$ Number of branches; $\mathrm{MSG}=$ Dry matter of branches, in $\mathrm{g}$ plant $^{-1}$; $\mathrm{NC}=$ Number of chapters; MSCA $=$ Dry matter of chapters, in $\mathrm{g} \mathrm{plant}^{-1} ; \mathrm{PRO}=$ Grain yield, in $\mathrm{kg} \mathrm{ha}^{-1} ; \mathrm{TGW}=$ Weight of a thousand grains, in $\mathrm{g}$ plant ${ }^{-1}$; OIL $=$ oil content in \%; PRO.O $=$ Oil productivity, in $\mathrm{kg} \mathrm{ha}^{-1}$.

Table 3. Pearson (r) linear correlation coefficients among safflower characters in autumn

\begin{tabular}{lllllllllllll}
\hline Characters & AP & DC & CC & MSC & NG & MSG & NC & MSCA & PRO & TGW & OIL & PRO.O \\
\hline AP & 1 & $0.44^{* *}$ & $0.86^{* *}$ & $0.48^{* *}$ & 0.16 & $0.29^{*}$ & $0.39^{* *}$ & $0.48^{* *}$ & $0.42^{* *}$ & $0.32^{*}$ & $0.36^{*}$ & $0.46^{* *}$ \\
DC & $0.44^{* *}$ & 1 & $0.32^{*}$ & $0.61^{* *}$ & $0.54^{* *}$ & $0.70^{* *}$ & $0.65^{* *}$ & $0.70^{* *}$ & 0.19 & 0.08 & -0.16 & 0.15 \\
CC & $0.86^{* *}$ & $0.32^{*}$ & 1 & $0.42^{* *}$ & 0.17 & 0.13 & $0.25^{*}$ & $0.36^{* *}$ & $0.49^{* *}$ & $0.27^{*}$ & $0.52^{* *}$ & $0.54^{* *}$ \\
MSC & $0.48^{* *}$ & $0.61^{* *}$ & $0.42^{* *}$ & 1 & $0.45^{* *}$ & $0.58^{* *}$ & $0.44^{* *}$ & $0.47^{* *}$ & 0.24 & 0.14 & 0.02 & 0.23 \\
NG & 0.16 & $0.54^{* *}$ & 0.17 & $0.45^{* *}$ & 1 & $0.50^{* *}$ & $0.68^{* *}$ & $0.57^{* *}$ & -0.04 & 0.04 & -0.01 & -0.05 \\
MSG & $0.29^{*}$ & $0.70^{* *}$ & 0.13 & $0.58^{* *}$ & $0.50^{* *}$ & 1 & $0.59^{* *}$ & $0.64^{* *}$ & 0.01 & 0.07 & $-0.30^{*}$ & -0.03 \\
NC & $0.39^{* *}$ & $0.65^{* *}$ & $0.25^{*}$ & $0.44^{* *}$ & $0.68^{* *}$ & $0.59^{* *}$ & 1 & $0.82^{* *}$ & -0.00 & 0.09 & -0.07 & -0.03 \\
MSCA & $0.48^{* *}$ & $0.70^{* *}$ & $0.36^{* *}$ & $0.47^{* *}$ & $0.57^{* *}$ & $0.64^{* *}$ & $0.82^{* *}$ & 1 & 0.18 & 0.05 & -0.06 & 0.15 \\
PRO & $0.42^{* *}$ & 0.19 & $0.49^{* *}$ & 0.24 & -0.04 & 0.01 & -0.00 & 0.18 & 1 & 0.02 & $0.41^{* *}$ & $0.97^{* *}$ \\
TGW & $0.31^{*}$ & 0.08 & $0.27^{*}$ & 0.14 & 0.04 & 0.07 & 0.09 & 0.05 & 0.02 & 1 & 0.26 & 0.06 \\
OIL & $0.36^{*}$ & -0.16 & $0.52^{* *}$ & 0.02 & -0.01 & $-0.30^{*}$ & -0.07 & -0.06 & $0.41^{* *}$ & 0.26 & 1 & $0.56^{* *}$ \\
PRO.O & $0.46^{* *}$ & 0.15 & $0.54^{* *}$ & 0.23 & -0.05 & -0.03 & -0.03 & 0.15 & $0.97^{* *}$ & 0.06 & $0.56^{* *}$ & 1 \\
\hline
\end{tabular}

Note. ${ }^{*}$ Significant at 5\% probability of error by Student's t-test, ${ }^{* *}$ Significant at $1 \%$ probability of error by Student's t-test. Legend: AP = Height of plant, in cm; DC = stem diameter, in $\mathrm{mm}$; CC = Length of stem in $\mathrm{cm}$; $\mathrm{MSC}=$ Dry matter of stem, in $\mathrm{g}_{\text {plant }}{ }^{-1} . \mathrm{NG}=$ Number of branches; $\mathrm{MSG}=$ Dry matter of branches, in $\mathrm{g}$ plant ${ }^{-1}$; $\mathrm{NC}=$ Number of chapters; MSCA $=$ Dry matter of chapters, in g plant ${ }^{-1} ; \mathrm{PRO}=$ Grain yield, in $\mathrm{kg} \mathrm{ha}^{-1} ; \mathrm{TGW}^{-}$ Weight of a thousand grains, in $\mathrm{g}_{\text {plant }}{ }^{-1} ; \mathrm{OIL}=$ oil content in \%; PRO.O = Oil productivity, in $\mathrm{kg} \mathrm{ha}^{-1}$.

The DC presented a higher degree of association in the autumn crop, whose higher $r$ values were observed for MSG, NC and MSCA. However, independent of the season, there is a trend of association of DC with the characteristics related to the accumulation of dry matter in safflower plants. The lowest degrees of association in the winter are related to the decrease of the diameter of the stem and the smaller lengthening of the internodes due to the little solar radiation.

As the AP, the CC despite showing significant correlations is not associated with growth components and grain production. Grain production and vegetative growth have a high degree of competition for nutrients, but climatic characteristics also influence final grain production. In early planting, NG is related to MSG, NC and MSCA, this difference is due to the low compensatory capacity of the plants in the winter period, due to the smaller cycle and the photoperiod, which makes difficult the formation of rhymes and consequently of chapters. 
In autumn and winter, MSC and MSG determined on flowering of safflower was associated with NC and MSCA until flowering, which is due to the transfer of the assimilates to the formation of biomass accumulation in the reproductive structures. Despite this, there was no association with grain yield at the end of the cycle. Thus, the accumulation of dry matter in the stem and branches is associated with the formation of chapters and consequently dry matter accumulation will not reflect higher grain yield. This is reflected in the non-existent association between the MSCA and the productive characters in both eras, and can be explained by the higher productive cycle of the safflower, being subject to abiotic stresses during the maturation phase.

The PRO.O constitutes a combination of PRO and OIL, thus follows a behavior similar to grain yield. Thus, as expected, grain yield and oil yield are highly associated with $\mathrm{r}$ of 0.97 and 0.98 , since the oil content is limited by genetic factors characteristic of the plant. In this sense, the OIL character, although significant, in both stations presented $\mathrm{r}$ of 0.53 and 0.56 , not being in association with the oil productivity. Koutroubas et al. (2009) observed that the classification among safflower genotypes for oil yield was similar to that of grain yield, because the oil yield was mainly determined by the latter. Omidi et al. (2012) also observed a high correlation between grain yield and oil content $\left(\mathrm{r}=0.90^{* *}\right)$.

Çamas et al. (2007), evaluating agronomic characteristics of the safflower cultivation in different conditions in the northern Turkey, found significant results for Pearson correlations for between grain yield with number of branches (0.49), grain weight (0.45), oil content ( 0.51$)$ and oil yield (0.95), number of branches with oil content $(0.34)$ and yield of oil (0.51), among number grains with grain weight $(0.53)$, oil content $(0.37)$ and oil yield (0.44), grain weight with oil content (0.29) and oil yield (0.39), oil content with oil yield (0.72). Vorpsi et al. (2010), evaluating the quality of safflower seeds cultivated in Albania, found significant relations for plant height with grain yield $(0.60)$, oil yield $(0.61)$, weight of chapters with grain weight $(0.40)$, and oil yield $(0.38)$, grain yield with oil yield (0.94).

The best behavior of the safflower characters in both seasons was that composed of three components, with 80 and $82 \%$ for autumn and winter, respectively (Table 4 ). The selection of the number of components was based on the principles suggested by Jolliffe (2002), that is, that the cumulative percentage of the total variance between 70 and $90 \%$ gives a reasonable idea of the representation of the original variance. It is observed that both in autumn and winter the three components explained a similar percentage of the variance of the variables, with 80 and $82 \%$ in autumn and winter respectively (Table 4 ).

Similarly, the first component explains $49 \%$ in the fall and $47 \%$ in the winter, although the score load indicates that the variability of the data is not explained by a single variable in the first component, that is, several components are responsible for determining variance of the data. In the second component, grain and oil productivity were highlighted in both seasons. In winter, due to the lower growth of the plant, the NG is an important factor, standing out in the second component. In autumn, due to the higher growth of safflower plants, plant height is an important variable, standing out in component three. On the other hand, due to lower productivity in winter, the oil content is a variable that explains the data variance and is important in component three. 
Table 4. Matrix of factorial weight of autumn and winter safflower characters in the three main components selected

\begin{tabular}{llllllll}
\hline \multirow{2}{*}{ Characters } & \multicolumn{3}{c}{ Autumn } & & \multicolumn{3}{c}{ Winter } \\
\cline { 2 - 3 } \cline { 6 - 7 } AP & PC1 & PC2 & PC3 & & PC1 & PC2 & PC3 \\
DC & -0.12 & -0.11 & 0.74 & & 0.34 & -0.24 & -0.27 \\
CC & 0.36 & -0.09 & 0.12 & & 0.38 & 0.13 & -0.04 \\
MSC & -0.29 & 0.07 & 0.49 & & 0.24 & -0.36 & -0.30 \\
NG & 0.33 & -0.10 & 0.37 & & 0.39 & 0.02 & -0.12 \\
MSG & 0.36 & -0.04 & -0.00 & & 0.12 & 0.42 & 0.33 \\
NC & 0.39 & -0.06 & 0.07 & & 0.37 & 0.21 & -0.01 \\
MSCA & 0.39 & -0.11 & 0.02 & & 0.31 & 0.33 & 0.17 \\
PRO & 0.38 & -0.08 & 0.00 & & 0.36 & 0.21 & 0.04 \\
TGW & -0.16 & -0.56 & -0.05 & & 0.22 & -0.41 & 0.22 \\
OIL & 0.02 & -0.30 & 0.09 & & 0.20 & -0.14 & 0.07 \\
PRO.O & -0.04 & -0.42 & -0.12 & & -0.01 & -0.19 & 0.70 \\
Eigenvalue & -0.15 & -0.58 & -0.09 & & 0.20 & -0.41 & 0.33 \\
\% explained variance & 49 & 22.7 & 14.7 & & 57.4 & 29.1 & 12.7 \\
\% accumulated variance & 49 & 19 & 0.1 & & 47 & 24 & 10
\end{tabular}

Note. $\mathrm{AP}=$ Plant height, in $\mathrm{cm} ; \mathrm{DC}=$ stem diameter, in $\mathrm{mm} ; \mathrm{CC}=$ Length of stem in $\mathrm{cm} ; \mathrm{MSC}=$ Dry matter of stem, in $\mathrm{g} \mathrm{plant}^{-1} . \mathrm{NG}=$ Number of branches; $\mathrm{MSG}=$ Dry matter of branches, in $\mathrm{g} \mathrm{plant}^{-1} ; \mathrm{NC}=$ Number of chapters; MSCA $=$ Dry matter of chapters, in $g_{\text {plant }}{ }^{-1} ; \mathrm{PRO}=$ Grain yield, in $\mathrm{kg} \mathrm{ha}^{-1}$; TGW $=$ Weight of a thousand grains, in g plant $^{-1}$; OIL $=$ oil content in $\%$; PRO.O $=$ Oil productivity, in $\mathrm{kg} \mathrm{ha}^{-1}$.

\section{Conclusion}

Except for the oil content and number of branches, the safflower characters were benefited by early sowing in autumn. Safflower cultivated in autumn in 2014 in southern Brazil produced 3,820 kg ha ${ }^{-1}$ and in winter produced 2,068 $\mathrm{kg} \mathrm{ha}^{-1}$.

At early autumn cultivation, the characters have more correlation, due to the climatic conditions. The yield of grains and oil has an association above $97 \%$ in both seasons.

The cultivation of safflower is extremely dependent on the climatic conditions, and it is not recommended to cultivate as a late crop (winter).

\section{Acknowledgements}

We want to give thanks to the Coordination for the Improvement of Higher Education Personnel (CAPES) by the scholarship of the master's degree and resources for conducting the research.

\section{References}

Alvares, C. A., Stape, J. L., Sentelhas, P. C., De Moraes Gonçalves, J. L., \& Sparovek, G. (2014). Köppen's climate classification map for Brazil. Meteorologische Zeitschrift, 22(6), 711-728. https://doi.org/10.1127/ 0941-2948/2013/0507

Ashri, A. (1975). Safflower germplasm evaluation. Plant Genetic Resources Newsletter, 31(1), 29-37.

Barteko, R., Andrade, A. R. de, \& Antoneli, V. (2010). A Influência da Variabilidade Climática e das Características Geomorfológicas na Produção e Produtividade Agrícola da Região Centro-Sul do Paraná. Paper presented at the XVI Encontro Nacional dos Geógrafos, Porto Alegre, Brazil. Retrieved from http://www.agb.org.br/evento/download.php?idTrabalho=3039

Bellé, R. A., Rocha, E. K., Backes, F. A. A. L., Neuhaus, M., \& Schwab, N. T. (2012). Safflower grown in different sowing dates and plant densities. Ciência Rural, 42(12), 2145-2152. https://doi.org/10.1590/ S0103-84782012005000106

Brăileanu, S. I., Kadar, R. R., Duda, M. M., Gocan, T. M., \& Moldovan, C. (2013). The Influence of Technological Elements on some Production Components for the Spring Wheat. Proenvironment/Promedi, 6(14), 379-383. 
Çamas, N., Çirak, C., \& Esendal, E. (2007). Seed yield, oil content and fatty acids composition of safflower (Carthamus tinctorius L.) Grown in northern turkey conditions. Journal of Faculty of Agriculture, 22(1), 98-104.

Colnago, L. A., Azeredo, R. B. V., Marchi Netto, A., Andrade, F. D., \& Venâncio, T. (2011). Rapid analyses of oil and fat content in agri-food products using continuous wave free precession time domain NMR. Magnetic Resonance in Chemistry, 49(Suppl. 1), 113-120. https://doi.org/10.1002/mrc.2841

Corleto, A., Cazzato, E., \& Annese, V. (2001). Potential yield of fall and spring-sown safflower as compared to sunflower, durum wheat and barley (pp. 191-196). Paper presented at the $5^{\text {th }}$ International Safflower Conference, Sidney, USA.

Elfadl, E., Reinbrecht, C., Frick, C., \& Claupein, W., (2009). Optimization of nitrogen rate and seed density for safflower (Carthamus tinctorius L.) production under low-input farming conditions in temperate climate. Field Crop Research, 114(1), 2-13. https://doi.org/10.1016/j.fcr.2009.06.012

Ghanbari-Odivi, A., Hashemzade, H., Bahrampour, B., \& Saeidi, M. (2013). Effect of sowing date on yield and its components, oil and protein concentration and some agronomical traits of safflower (Carthamus tinctorius L.). Technical Journal of Engineering and Applied Sciences, 3(14), 1405-1410.

Istanbulluoglu, A. (2009). Effects of irrigation regimes on yield and water productivity of safflower (Carthamus tinctorius L.) under Mediterranean climatic conditions. Agricultural Water Management, 96(12), 1792-1798. https://doi.org/10.1016/j.agwat.2009.07.017

Istanbulluoglu, A., Gocmen, E., Gezer, E., Pasa, C., \& Konukcu, F. (2009). Effects of water stress at different development stages on yield and water productivity of winter and summer safflower (Carthamus tinctorius L.). Agricultural Water Management, 96(10), 1429-1434. https://doi.org/10.1016/j.agwat.2009.04.004

Jolliffe, I. (2002). Principal component analysis. John Wiley \& Sons, Ltd.

Kaffka, S. R., \& Kearney, T. E. (1998). Safflower production in California. UC Agriculture and Natural Resources, Publication 21565 (p. 29). Davis, USA.

Kar, G., Kumar, A., \& Martha, M. (2007). Water use efficiency and crop coefficients of dryseason oilseed crops. Agricultural Water Management, 87(1), 73-82. https://doi.org/10.1016/j.agwat.2006.06.002

Koutroubas, S. D., Papakosta, D. K., \& Doitsinis, A. (2004). Cultivar and seasonal effects on the contribution of pre-anthesis assimilates to safflower yield. Field Crop Research, 90(2-3), 263-274. https://oi.org/10.1016/ j.fcr.2004.03.009

Koutroubas, S. D., Papakosta, D. K., \& Doitsinis, A. (2009). Phenotypic variation in physiological determinants of yield in spring sown safflower under Mediterranean conditions. Field Crops Research, 112(2-3), 199-204. https://doi.org/10.1016/j.fcr.2009.03.002

Lovelli, S., Perniola, M., Ferrara, A., \& Di Tommaso, T. (2007). Yield response factor towater (Ky) and water use efficiency of Carthamus tinctorius L. and Solanum melongena L. Agricultural Water Management, 92(1-2), 73-80. https://doi.org/10.1016/j.agwat.2007.05.005

Ministério da Agricultura, Pecuária e Abastecimento. (2009). Regras para análise de sementes (p. 399). Ministério da Agricultura, Pecuária e Abastecimento, Secretaria de Defesa Agropecuária. Brasília: Mapa/ACS.

Mostafanezhad, M., \& Eivazi, Ar. (2010). Planting date effect on yield and yield componente of safflower genotypes under Uromiacondition. Journal of Research in Agronomical Science, 10(1), 33-43.

Omidi, A. H., \& Sharifmoghadas, M. R. (2010). Evaluation of Iranian safflower cultivars reaction todifferent sowing dates and plant densities. World Applied Science Journal, 8(8), 953-958.

Omidi, A. H., Khazaei, H., Monneveux, P., \& Frederick Setoddard, F. (2012). Effect of cultivar and water regime on yield and yield components in safflower (Carthamus tinctorius L.). Turkish Journal of Field Crops, 17(1), 10-15.

Oyen, L. P. A., \& Umali, B. E. (2007). Carthamus tinctorius L. In H. van der Vossen, \& G. S. Mkamilo (Eds.), Prota 14: Óleos vegetais/oléagineux. Wageningen, Holanda.

Peixoto, C. P., Goncalves, J. A., Peixoto, M. F. S. P., \& Carmo, D. O. (2008). Características agronômicas e produtividade de amendoim em diferentes espaçamentos e épocas semeadura no Recôncavo Baiano. Bragantia, 67(3), 563-568. https://doi.org/10.1590/S0006-87052008000300016 
Quiroga, A. R., Díaz-Zorita, M., \& Buschiazzo, D. E. (2001). Safflower productivity as related to soil water storage and management practices in semiarid regions. Communications in Soil Science and Plant Analysis, 32(17-18), 2851-2862. https://doi.org/10.1081/CSS-120000967

Rao, V. P., Reddy, D. R., Reddy, B. B., \& Rao, L. J. (1990). Performance of safflower genotypes at varying plant densities. Journal of Research APAU, 18(2), 180-182.

Salera, E. (1997). Production potential of safflower (Carthamus tinctorius L.) in Tuscany (pp. 115-118). Paper presented at the $4^{\text {th }}$ International Safflower Conference. Bari, Italy.

Santos, H. G., et al. (2013). Sistema Brasileiro de Classificação de Solos (4th ed., p. 353). Rio de Janeiro, RJ: Embrapa Solos.

Santos, R. F., \& Silva, M. A. (2015). Carthamus tinctorius L.: Uma alternativa de cultivo para o Brasil. Acta Iguazu, 4(1), 26-35.

Santos, R. F., Silva, M. A., Klar, A. E., Zanotto, M. D., \& Bassegio, D. (2015). Comportamento morfológico no período de crescimento de genótipos de Carthamus tinctorius L. em cultivo sob sequeiro e irrigado. Revista Brasileira de Energias Renováveis, 4(1), 146-167. https://doi.org/10.5380/rber.v4i1.42120

Si, R., \& Walton, G. H. (2004). Determinants of oil concentration and seed yield in canola and Indian mustard in the lower rainfall areas of Western Australia. Australian Journal of Agricultural Research, 55(3), $367-377$. https://doi.org/10.1071/AR03151

Tayebi, A., Afshari, H., Farahvash, F., Sinki, J. M., \& Nezarat, S. (2012). Effect of drought stress and different planting dates on safflower yield and its components in Tabriz region. Iranian Journal of Plant Physiology, 2(3), 445-453.

Vorpsi, V., Harizaj, F., Bardhi, N., Vladi, V., \& Dodona, E. (2010). Carthamus tinctorius L. the quality of safflower seeds cultivated in Albania. Research Journal of Agricultural Science, 42(1), 326-331.

Wrege, M. S., Steinmetz, S., Garrastazu, M. C., Reisser Júnior, C., Almeida, I. R., Caramori, P. H., ... Braga, H. J. (2009). Atlas Climáticos dos Estados da Região Sul do Brasil. Paper presented at the XVI Congresso Brasileiro de Agrometereologia. Belo Horizonte, Brazil. Retrieved from https://ainfo.cnptia.embrapa.br/ digital/bitstream/item/56819/1/SP5493.pdf

Yau, S. K. (2007). Winter versus spring sowing of rain-fed safflower in a semi-arid, high-elevation Mediterranean environment. European Journal of Agronomy, 26(3), 249-256. https://doi.org/10.1016/j.eja. 2006.10.004

\section{Copyrights}

Copyright for this article is retained by the author(s), with first publication rights granted to the journal.

This is an open-access article distributed under the terms and conditions of the Creative Commons Attribution license (http://creativecommons.org/licenses/by/4.0/). 